\title{
Variability and genetic diversity study in an advanced segregating population of rice with bacterial blight resistance genes introgressed
}

\section{Estudo de variabilidade e diversidade genética em uma população de arroz em segregação avançada com genes introgredidos de resistência à ferrugem bacteriana}

\author{
Ponnaiah Govintharaj ${ }^{1 *}$, Swaminathan Manonmani', Sabariappan Robin ${ }^{1}$ \\ ${ }^{1 T}$ Tamil Nadu Agricultural University, Department of Plant Breeding and Genetics, Centre for Plant Breeding and Genetics, Coimbatore, Tamil Nadu, India \\ ${ }^{*}$ Corresponding author: govinth.tnau@gmail.com \\ Received in April 26, 2018 and approved in July 5, 2018
}

\begin{abstract}
Bacterial blight disease of rice caused by Xanthomonas oryzae pv. oryzae is one of the most important widespread disease around the globe and can cause severe yield reductions of up to $30 \%$ of the total yield. Genetic variability was studied in 54 families of CB 174 R $\times$ IRBB 60 rice with bacterial blight resistance genes introgressed at the Department of Rice, Tamil Nadu Agricultural University, Coimbatore, India. Traits such as plant height and the number of productive tillers per plant were found to have negative skewness in this study, indicating the duplication of gene effects. Panicle length and the number of grains per panicle were found to have positive kurtosis, indicating gene interactions. The phenotypic coefficient of variation was slightly higher than the genotypic coefficient of variation for all traits, indicating that the observed variation was not only due to genotypic but also due to the environmental effect on the expression of these traits. High heritability coupled with high genetic advance as a percent of the mean was observed for plant height. Moreover, moderate heritability coupled with high genetic advance as a percent of the mean was observed for the single plant yield of rice. Cluster and principal component analyses revealed that the $54 \mathrm{~F}_{2: 3}$ families were grouped into three clusters based on six agro-morphological traits. Clusters III and II had higher mean values for most of the studied traits than cluster I. Intercrossing lines from distinct clusters can be identified and crossed to generate larger variability to produce desirable recombinants for higher yield with a wide genetic base.
\end{abstract}

Index terms: Rice breeding; heritability; principal component analysis.

\begin{abstract}
RESUMO
A ferrugem do arroz, causada pela bactéria Xanthomonas oryzae pv. oryzae, é uma das doenças mais importantes e amplamente difundidas em todo o mundo, que pode causar reduções severas de produtividade, podendo atingir perdas da ordem de $30 \%$ do rendimento total. A variabilidade genética do arroz foi estudada em 54 famílias de CB 174 R $\times$ IRBB 60 com genes de resistência bacteriana introgredidos, no Departamento de Arroz da Universidade Agrícola de Tamil Nadu, Coimbatore, na Índia. Características como a altura das plantas e o número de perfilho produtivos por planta apresentaram assimetria negativa neste estudo, indicando a duplicação dos efeitos dos genes. O comprimento da panícula e o número de grãos por panícula apresentaram uma curtose positiva, indicando interações entre os genes. 0 coeficiente de variação fenotípica foi ligeiramente superior ao coeficiente de variação genotípico para todas as características, sugerindo que a variação observada não foi resultante apenas do genótipo, mas também devido ao efeito ambiental sobre a expressão dessas características. A alta herdabilidade aliada ao alto avanço genético foi observada para a altura das plantas. Além disso, a herdabilidade moderada, e o avanço genético elevado, foram observados para a produtividade de uma única planta de arroz. Análises de agrupamentos e componentes principais revelaram que as 54 famílias $F_{2: 3}$ foram divididas em três grupos baseados em seis características morfológicas. Os clusters III e II apresentaram valores médios mais elevados para a maioria das características estudadas que o cluster I. As linhagens de intercruzamento de clusters distintos podem ser identificadas e cruzadas para gerar maior variabilidade para produzir recombinantes desejáveis para maior rendimento com uma ampla base genética.
\end{abstract}

Termo de indexação: Melhoramento de arroz; herdabilidade; análise de componentes principais.

\section{INTRODUCTION}

Rice (Oryza sativa L.) is one of the most important staple food crop in the world. Bacterial blight (BB) is the most devastating disease in rice caused by Xanthomonas oryzae pv. oryzae (Xoo), resulting in a 20 to $30 \%$ annual reduction in rice production worldwide (NiÑo; Ronald; Bogdanove, 2006). Conventionally, BB has been controlled using chemical pesticides and biocontrol agents such as plant extracts (Nisha et al., 2012) and chitosan solutions (Liu et al., 2012). Because of environmental and food safety issues, chemical control is not feasible, practical, or effective (Sidhu; Khush; Mew, 1978), and therefore, the development and introduction of resistant cultivars is the most effective, economical and eco-friendly method 
for controlling the disease (Ogawa, 1993). Variability estimates for yield and other components of yield characteristics are important before planning appropriate breeding methodologies for crop improvement. Heritability studies in plant breeding programs are mainly used to determine how much variation in the phenotype in a population is due to the genetic variation between individuals in that population. According to Ibrahim and Hussein (2006) and Nwangburuka et al. (2012), traits with high genotypic coefficients of variation as well as with high heritability and genetic advance as a percent of the mean could be controlled by additive types of gene action; hence, traits can be improved by simple breeding methodologies.

Information on skewness and kurtosis provides the nature of gene action (Fisher; Immer; Tedin, 1956) and gene numbers controlling the trait (Robson, 1956). If the kurtosis value on the characters is a positive sign, this indicates the presence of gene interactions, whereas a negative sign or a value near zero for kurtosis indicates the absence of gene interactions (Kotch; Ortiz; Ross, 1992). Skewness in the positive direction reveals the presence of complementary gene action, while the gene action is duplicate (additive $\times$ additive) when skewness has a negative sign (Vanitha et al., 2016).

Therefore, the present study aimed to determine the genetic variability and diversity among yield and yield component traits of bacterial blight resistance genes introgressed into segregating populations of rice.

\section{MATERIAL AND METHODS}

Experimental materials comprised hybrid parents of the recently released hybrids in TNAU. CB $174 \mathrm{R}$ is the restorer line of rice hybrid CORH 4 (COMS 23A / CB $174 \mathrm{R}$ ) and is well known for a medium slender grain type that matures in 135 days. IRBB 60 is a donor parent for bacterial blight resistant genes $X a 21, x a 13$ and $x a 5$. The present study was conducted at the Department of Rice, Tamil Nadu Agricultural University, Coimbatore, India. The area is located at latitude $11^{\circ} 00^{\prime} \mathrm{N}$ and longitude $77^{\circ} 00^{\prime}$ and an elevation 427.00 meters above mean sea level. Standard cultural practices were followed to grow healthy crops.

\section{Field data collection}

At the maturity stage, data were collected and recorded from nine plants of $54 \mathrm{~F}_{2: 3}$ families according to IRRI (2002) rice descriptors. The traits, such as plant height, the number of productive tillers, panicle length, the number of grains per panicle, thousand grain weight and single plant yield, were collected and recorded.

\section{Data analysis}

Data were used to estimate variability using simple measurements such as the mean and range; components of variation such as genotypic coefficient of variation (GCV) and phenotypic coefficient of variation (GCV); genetic parameters such as heritability and genetic advance as a percent of the mean; and genetic diversity. All the parameters in this study were measured in the $54 \mathrm{~F}_{2: 3}$ families using Microsoft Excel 2007 (Microsoft Crop., Redmond, WA, USA). Cluster analysis was performed on the basis of phenotypic traits in DARwin 6.0 software (Perrier; Flori; Bonnot, 2003) to construct a dendrogram using both Ward's Minimum Variance method and the Neighbor-Joining method. Principal component analysis (PCA) was performed using XLSTAT software (https:// www.xlstat.com/en/).

\section{RESULTS AND DISCUSSION}

\section{Variability studies in $\mathbf{F}_{2: 3}$}

The values of the mean, range, genotypic and phenotypic variance, phenotypic and genotypic coefficient of variance, heritability, genetic advance and genetic advance as a percent of the mean for seven different characters are presented in Table 1.

Plant height and the number of productive tillers per plant showed negative skewness under this study, indicating duplicate gene effects, while all other characters exhibited positive skewness, suggesting complementary gene action. Contradictory results have been previously reported by Ponnaiah et al. (2017)

Panicle length and the number of grains showed positive kurtosis, indicating gene interactions, while other yield and yield-related characteristics showed an absence of gene interactions. Nachimuthu et al. (2014) reported that panicle length and the number of grains per panicle showed positive kurtosis in rice.

\section{Phenotypic and genotypic variance}

The highest phenotypic and genotypic variance was observed for the number of grains per panicle (858.36\% and $373.16 \%$, respectively) and plant height (236.38\% and $204.67 \%$, respectively), while high phenotypic and moderate genotypic variance was 
observed for single plant yield $(40.82 \%$ and $16.31 \%$, respectively). Low phenotypic and genotypic variance was observed for the number of productive tillers per plant $(6.86 \%$ and $2.17 \%$, respectively), panicle length (4.51\% and $1.47 \%$, respectively) and thousand grain weight (3.67\% and $0.68 \%$, respectively). This study shows that phenotypic variations were higher than genotypic variations for all the studied traits, indicating a considerable influence of environment on the expression of these traits.

\section{Genotypic and phenotypic coefficient of variation}

The GCV was found to be less than the PCV for all the traits under investigation, indicating that the observed variation was not only controlled by genotype but also influenced by environmental effects on the expression of the traits. Moderate GCV and high PCV were observed for single plant yield (16.04\% and $25.38 \%$, respectively) and the number of productive tillers per plant $(11.74 \%$ and $20.86 \%$, respectively). Similar results were reported earlier by Govintharaj et al. (2016). Moderate GCV and PCV were observed for plant height $(12.59 \%$ and $13.53 \%$, respectively) and the number of grains per panicle $(12.21 \%$ and $18.53 \%$, respectively), which suggests the possibility of improving these characters by further selection in segregating generations. These findings are consistent with Govintharaj et al. (2016) for plant height and Ponnaiah, Manonmani and Robin (2016) for the number of grains per panicle. Low PCV and PCV were observed for panicle length $(4.65 \%$ and $8.15 \%$, respectively) and thousand grain weight $(4.33 \%$ and $8.15 \%$, respectively). These results are in agreement with Ponnaiah, Manonmani and Robin (2016) for panicle length and Govintharaj et al. (2016) for thousand grain weight. In $\mathrm{F}_{2: 3}$ families, the variability parameters recorded were very low because stringent selection was imposed in the $\mathrm{F}_{2}$ generation and selection was effective
(Govintharaj et al., 2017). The current study showed that a wide range of variability was exhibited for the traits under this study.

\section{Heritability and genetic advance}

Estimates of heritability were high for all the characters studied. High heritability and genetic advance as a percent of the mean was observed for plant height ( $86.58 \%$ and $24.15 \%$, respectively), which showed that the presence of additive gene action for trait expression can be improved by simple selection. This finding is supported by Govintharaj et al. (2016) and Ameenal et al. (2016). Moderate heritability and genetic advance were observed as the percent of the mean observed for the number of grains per panicle $(39.96 \%$ and $16.59 \%$, respectively) and the number of productive tillers per plant $(31.69 \%$ and $13.62 \%$, respectively). These results are in agreement with Govintharaj et al. (2016) for the number of grains per panicle and Fiyaz et al. (2011) for the number of productive tillers per plant. Moderate heritability and high genetic advance as a percent of the mean was observed for single plant yield (39.96\% and $20.89 \%$, respectively), which suggests that simple selection would be effective in later generation advancement. On the other hand, moderate heritability and low genetic advance as a percent of the mean was registered for panicle length $(39.96 \%$ and $5.47 \%$, respectively), indicating that the environment is influenced by phenotypic expression. Hence, direct selection for these traits will be less effective. This finding was supported by Ponnaiah, Manonmani and Robin (2016). Low heritability and genetic advance as a percent of the mean was observed for thousand grain weight (18.84\% and $3.87 \%$, respectively), which suggests that nonadditive gene action plays a major effect. This result was in agreement with research by Abebe, Alamerew and Tulu (2017).

Table 1: Variability parameters of different biometrical traits in a $F_{2: 3}$ population in rice.

\begin{tabular}{crcrrrrrrrc}
\hline Traits & Mean & Range & \multicolumn{1}{c}{ GV } & \multicolumn{1}{c}{ PV } & GCV & PCV & h $^{2}(\%)$ & GA of mean\% & Skewness & Kurtosis \\
\hline PH & 113.56 & $87.61-141.67$ & 204.67 & 236.38 & 12.59 & 13.53 & 86.58 & 24.15 & -0.25 & -0.91 \\
NPT & 12.56 & $8.56-16.67$ & 2.17 & 6.86 & 11.74 & 20.86 & 31.69 & 13.62 & -0.05 & -0.76 \\
PL & 26.04 & $23.28-30.78$ & 1.47 & 4.51 & 4.65 & 8.15 & 32.59 & 5.47 & 0.72 & 0.62 \\
NG & 158.11 & $18.11-235.11$ & 373.16 & 858.36 & 12.21 & 18.53 & 43.47 & 16.59 & 0.30 & 1.35 \\
TGW & 19.10 & $16.31-22.60$ & 0.68 & 3.63 & 4.33 & 9.97 & 18.84 & 3.87 & 0.28 & 0.05 \\
SPY & 25.18 & $16.02-38.89$ & 16.31 & 40.82 & 16.04 & 25.38 & 39.96 & 20.89 & 0.47 & -0.06 \\
\hline
\end{tabular}

Note: PH: Plant height (cm); NPT: Number of productive tillers; PL: Panicle length $(\mathrm{cm})$; NG: Number of grains per panicle; TGW: Thousand grain weight (g); SPY: Single plant yield (g). 


\section{Genetic diversity analysis}

A total of 54 families based on six phenotypic traits delineated into three clusters, with 17 families in the first cluster (designated C-I), 22 in C-II and 15 in C-III (Table 2 and Figure 1). The families classified in cluster III had higher mean values for all the traits studied. Cluster
II had lower mean values than cluster III but higher than cluster I for all traits except the number of productive tillers and single plant yield. This study provides information to select better recombinants for various traits. Thus, this information could be used to generate greater variability in future rice breeding programs.

Table 2: Cluster means and range for yield and yield-contributing traits in rice.

\begin{tabular}{cccc}
\hline Traits & C-I & C-II & C-III \\
\hline PH & $99.66(87.61,117.28)$ & $117.16(93.28,141.67)$ & $124.03(111.61,140.67)$ \\
NPT & $13.31(9.11,15.11)$ & $10.76(8.56,12.11)$ & $14.34(12,16.67)$ \\
PL & $25.08(23.61,26.56)$ & $25.68(23.28,28.17)$ & $27.68(25.56,30.78)$ \\
NG & $143.41(108.11,168.44)$ & $157.89(112,190)$ & $175.1(142.22,235.11)$ \\
TGW & $18.57(16.31,21.08)$ & $19.26(16.73,22.6)$ & $19.47(17.13,21.59)$ \\
SPY & $23.97(16.02,32.34)$ & $22.11(18.35,26.36)$ & $31.04(27.24,38.89)$ \\
\hline
\end{tabular}

Note: PH: Plant height (cm); NPT: Number of productive tillers; PL: Panicle length (cm); NG: Number of grains per panicle; TGW: Thousand grain weight (g); SPY: Single plant yield (g).

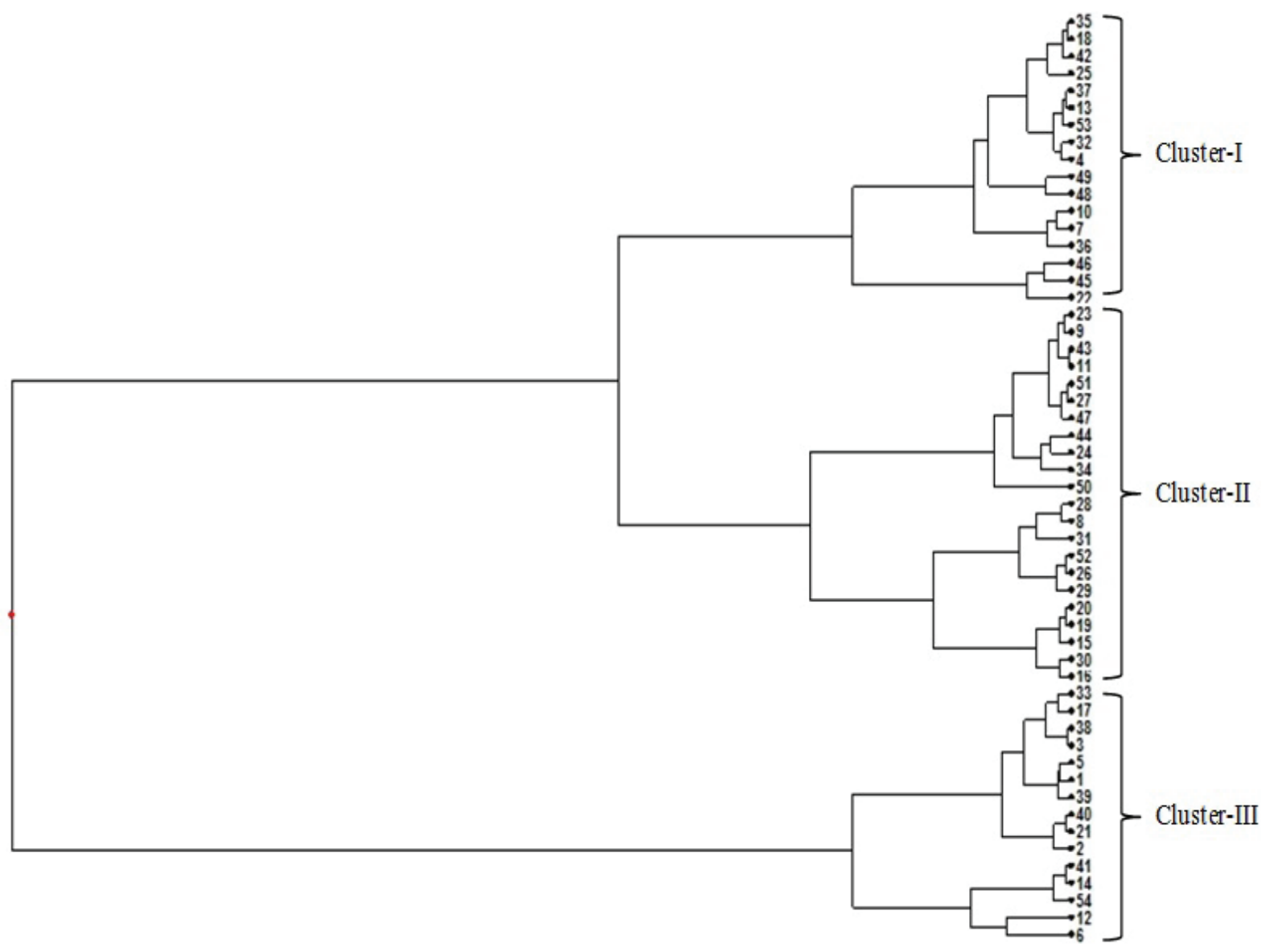

Figure 1: Dendrogram constructed for $54 \mathrm{~F}_{2: 3}$ families of rice. 
Principal component analysis (PCA) is a powerful tool and the most basic multivariate data reduction statistical technique. The results of PCA revealed that two out of six principal components were significant (Eigen value $>1$ ) and contributed $64.5 \%$ of the total variation (Table 3 and Figure 2). PC 1 accounted for $42.7 \%$ and PC 2 accounted for $22 \%$ of the total variation. PCA found the same grouping pattern as found in the cluster analysis, indicating that significant variation exists in this study. The separation of PC 1 and PC 2 showed that 54 families were dispersed in all quarters, indicating a high level of genotypic variation among the families. Families 6, $5,20,26,32,52$ and 8 and traits such as single plant yield, panicle length, the number of grains per panicle and the number of productive tillers per plant showed more variation than any other and were located close to the axis line.

Table 3: Principal components, Eigen values and proportion of variation of $54 \mathrm{~F}_{2: 3}$ families in rice.

\begin{tabular}{cccc}
\hline Principal component & Eigen value & Proportion of variation (\%) & Cumulative variation (\%) \\
\hline PC 1 & 2.56 & 42.66 & 42.66 \\
PC 2 & 1.32 & 22.03 & 64.69 \\
PC 3 & 0.94 & 15.71 & 80.40 \\
PC 4 & 0.76 & 12.75 & 93.15 \\
PC 5 & 0.25 & 4.18 & 97.33 \\
PC 6 & 0.16 & 2.67 & 100.00 \\
\hline
\end{tabular}

Cumulative $(64.69 \%)$

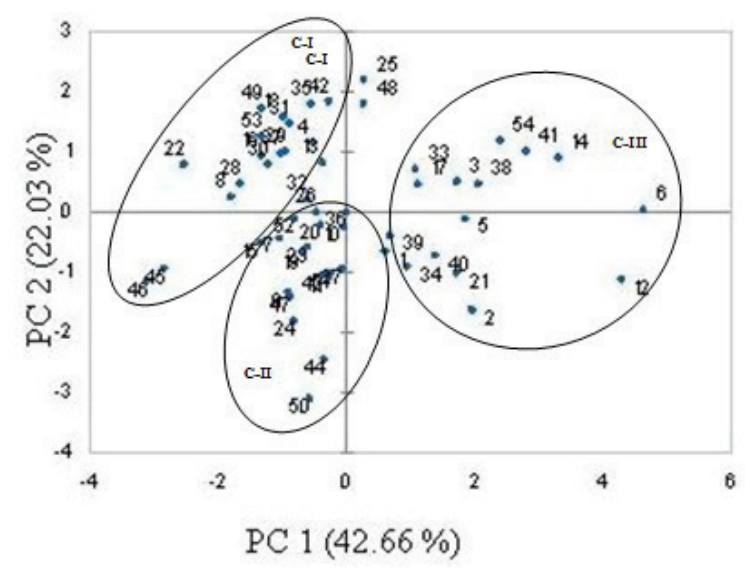

a) Biplot
Cumulative $(64.69 \%)$

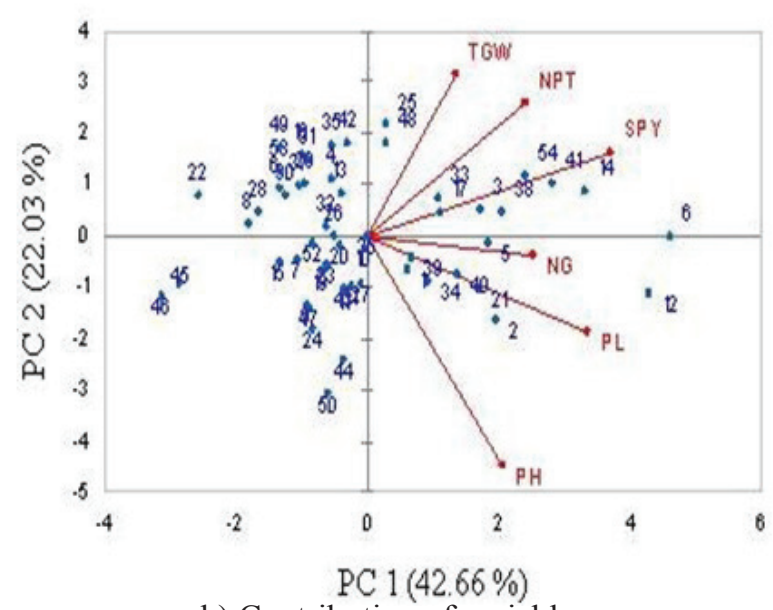

b) Contribution of variables

Figure 2: Principal component analysis (PCA) performed on $54 \mathrm{~F}_{2: 3}$ families in rice. 


\section{CONCLUSIONS}

Variability existed among $54 \mathrm{~F}_{2: 3}$ families. Selection could be effective for plant height, while selection would be effective in later generations for all other traits under study. Cluster analysis and PCA would allow the selection of desirable recombinants for various traits and could be used to generate greater variability in future rice breeding programs.

\section{REFERENCES}

ABEBE, T.; ALAMEREW, S.; TULU, L. Genetic variability, heritability and genetic advance for yield and its related traits in rainfed lowland rice (Oryza sativa L.) genotypes at Fogera and Pawe, Ethiopia. Advances in Crop Science and Technology, 5(2):272, 2017.

AMEENAL, M. et al. Assessment of parental genetic variability in rice. International Journal of Agricultural Science, 8(54):2917-2919, 2016.

FISHER, R. A.; IMMER, F. R.; TEDIN, O. The genetical interpretation of statistics of the third degree in the study of quantitative inheritance. Genetics, 17:107-124, 1956.

FIYAZ, A. R. et al. Genetic variability, correlation and path coefficient analysis studies in rice (Oryza sativa L.) under alkaline soil condition. Electronic Journal of Plant Breeding, 2(4):531-537, 2011.

GOVINTHARAJ, P. et al. Effectiveness of selection, parentoffspring correlation and regression in bacterial blight resistance genes introgressed rice segregating population. Ciência Rural, 47:09e20160987, 2017.

GOVINTHARAJ, P. et al. Genetic parameters studies on bacterial blight resistance genes introgressed segregating population in Rice. World Scientific News, 59:85-96, 2016.

IBRAHIM, M. M.; HUSSEIN, R. M. Variability, heritability and genetic advance in some genotypes of roselle (Hibiscus sabdariffa L.). World Journal of Agricultural Science, 2:340-345, 2006.

IRRI. Standard evaluation system for rice. International Rice Research Institute, Los Banos, Manila, Philippines. 2002. 56p.

KOTCH, G. P.; ORTIZ, R.; ROSS, W. M. Genetic analysis by use of potato haploid populations. Genome, 35:103-108, 1992.

LIU, H. et al. Antifungal effect and mechanism of chitosan against the rice sheath blight pathogen, Rhizoctonia solani. Biotechnology Letters, 34:2291-2298, 2012.

NACHIMUTHU, V. V. et al. Evaluation of rice genetic diversity and variability in a population panel by principal component analysis. Indian Journal of Science and Technology, 7(10):1555-1562, 2014

NIÑO, D. O.; RONALD, P. C.; BOGDANOVE, A. J. Xanthomonas oryzae pathovars: Model pathogens of a model crop. Molecular Plant Pathology, 7:303-324, 2006.

NISHA, S. et al. Effect of plant compounds on induced activities of defense-related enzymes and pathogenesis related protein in bacterial blight disease susceptible rice plant. Physiology and Molecular Plant Pathology, 80:1-9, 2012.

NWANGBURUKA, C. C. et al. Genetic variability and heritability in cultivated okra [Abelmoschus esculentus (L.) Moench]. Spanish Journal of Agricultural Research, 10(1):123129, 2012.

OGAWA, T. Methods and strategy for monitoring race distribution and identification of resistance genes to bacterial leaf blight (Xanthomonas campestris pv. oryzae) in rice. Japan Agricultural Research Quarterly, 27:7180, 1993.

PERRIER, X.; FLORI, A.; BONNOT, F. Methods for data analysis. In: HAMON, P. et al. (Ed). Genetic diversity of cultivated tropical plants. Science Publishers, Inc and Cirad, Montpellier, p.31-63, 2003.

PONNAIAH, G. S. T.; MANONMANI, S.; ROBIN, S. Estimates of genetic variability, heritability and genetic advance for blast resistance gene introgressed segregating population in rice. International Journal of Current Microbiology and Applied Science, 5(12):672-677, 2016.

PONNAIAH, G. S. T. et al. Genetic variability for yield and yield components characters in bacterial blight and blast resistance genes introgressed backcross populations in rice. International Journal of Current Microbiology and Applied Science, 6(2):100-103, 2017.

POONI, H. S.; JINKS J. L.; CORNISH, M. A. The causes and consequences of non normality in predicting the properties of recombinant inbred lines. Heredity, 38:329338, 1977.

ROBSON, D. S. Application of K4 statistics to genetic variance component analysis. Biometrics, 12:433-44, 1956.

SIDHU, G. S.; KHUSH, G. S.; MEW, T. W. Genetic analysis of bacterial blight resistance in seventy four cultivars of rice, Oryza sativa L. Theoretical and Applied Genetics, 53:105-111.1978.

VANITHA, J. et al. Genetic variability studies for zinc efficiency in aerobic rice. Sabrao Journal Breeding and Genetics, 48(4):425-433, 2016. 